This is a post-print version of the paper:

Müller, C., Hofmann, V., Fleischli, J. \& Studer, F. (2016). Classroom peer influence from the entire class, dominant students, and friends. Journal of Cognitive Education and Psychology, 15, 122-145.

http://dx.doi.org/10.1891/1945-8959.15.1.122

https://connect.springerpub.com/content/sgrjcep/15/1/122 


\title{
Classroom Peer Influence from the Entire Class, Dominant Students, and Friends
}

\begin{abstract}
Recent research indicates that the development of antisocial behavior among students is influenced by the behavioral characteristics of their classmates. However, not all peers in a given class may exert the same influence. Thus, we examined the extent to which individual development is predicted by the perceived proportion of all students with antisocial behavior in the classroom, socially dominant students, and friends. A short-term longitudinal study comprising four measurements was conducted on seventh grade students. In total, 825 students completed self- and peer-reports on aggressive, delinquent, and disruptive classroom behavior. Longitudinal, multilevel negative binomial analyses showed that the perceived characteristics of the entire classroom, dominant students, and friends in one's class significantly predicted self-reported aggressive and disruptive behavioral development, but not delinquency. The impact of the three social groups under study in this regard did not differ significantly. Classroom effects were independent of students' out-of-classroom friend influences.
\end{abstract}

\section{Introduction}

Antisocial behavior in early adolescence includes aggressive and delinquent acts as well as less severe forms of rule breaking such as disruptive classroom behavior (Loeber, White, \& Burke, 2012). These behaviors are not only challenging to teachers and peers, but they also pose risks to the affected individuals' development. For example, students who exhibit high levels of antisocial behavior have an increased risk of experiencing learning difficulties and psychiatric problems (Hinshaw, 1992; Nock, Kazdin, Hiripi, \& Kessler, 2006). With regard to the influence of school-related factors on behavioral development, recent research has 
emphasized teachers' classroom management capabilities and their relationships with students (Evertson \& Weinstein, 2006; Tsai \& Cheney, 2012). Other studies have indicated the importance of factors relating to individual students such as their impulsiveness (Vile Junod, DuPaul, Jitendra, Volpe, \& Cleary, 2006) or parental background (Hill et al., 2004).

In addition, antisocial behavior is affected by the peers who exert influence based on processes such as social modeling, social reinforcement, or fear of peer rejection of the concerned individuals (Akers, 2009; Bandura, 1977; Warr, 2002). In fact, a long tradition of peer influence research shows that friends and members of cliques influence each other in an interplay between selection and socialization (for an overview, see Dishion \& Tipsord, 2011). While this line of research focused mostly on influences within self-selected peer groups (i.e., cliques at school or in the neighborhood), the classroom as a not self-selected, involuntary peer group, also provides an important context for peer interaction. Indeed, classroom composition research showed that the level of antisocial behavior in a classroom as a whole predicts the individual behavior of students (e.g., Barth, Dunlap, Dane, Lochmann, \& Wells, 2004; Kellam, Ling, Merisca, Brown, \& Ialongo, 1998; Mercer, McMillen, \& DeRosier, 2009; Powers, Bierman, \& CPRG, 2013; Thomas, Bierman, \& CPRG, 2006; Araos, Cea, Fernández, \& Valenzuela, 2014).

This study aims to combine peer influence research focusing on specific social subgroups and the approach of classroom composition research looking at entire classrooms within one study. This may help to understand how the influences of different groups within a classroom relate to each other. For example, the question can be answered whether the entire classroom or specific subgroups in a class exert the most influence on individual students. To answer these questions, we evaluated and compared the impact of the perceived behavioral characteristics of three groups of classmates on individual antisocial development of early adolescents. The first group encompassed all the students in a classroom, the second group 
was students perceived as socially dominant, and the third group was classmates who were friends with the participating students.

\section{The Impact of the Behavior of the Entire Classroom on Individual Development}

In the first group, individual students may observe a specific proportion of students in their class exhibiting antisocial behavior (e.g., someone perceiving that 10 out of 20 of his or her classmates were rude to the teacher in the previous week). This observation can influence an individual through different mechanisms. For instance, classroom disruptions or direct forms of aggression are usually quite visible in the school context. Consequently, the scripts for these behaviors can be easily established from direct observation (Bandura, 1977; Huesmann, \& Eron, 1989).

In contrast, "real-time" observational learning may occur less often in instances of indirect aggression or secretly performed delinquent acts. The occurrence of such less visible behaviors is often communicated verbally or via social media (Rimal \& Real, 2003; Hinduja \& Patchin, 2008; Moreno, Parks, Zimmerman, Brito, \& Christakis, 2009). Research on deviant talk, for example, shows that verbalizations of deviant behavior and the reinforcements following such utterances (e.g. laughing) are a central process underlying peer influence (Dishion \& Tipsord, 2011). Social learning and communicative processes can thus be expected to set the classroom norms regarding antisocial behavior (Cialdini, Kallgren, \& Reno, 1990). Contradicting these norms may go along with fear of peer rejection and mockery (Warr, 2002).

Earlier studies support the idea that the level of antisocial behavior in the classroom as a whole influences students' future antisocial behavior (e.g., Kellam et al., 1998; Mercer et al., 2009; Powers et al., CPRG, 2013; Thomas et al., 2006). For example, in a study of Mercer and colleagues (2009) students in classes with higher mean levels of teacher-reported aggression reported greater increases in self-reported aggression over the school year. 
Moreover, previous analyses of data obtained from the Swiss sample referred to in this article have shown that the means of self-reported aggressive and delinquent behaviors in a classroom predicted individual behavioral development (Müller, Hofmann, Fleischli, \& Studer, 2015). Extending these findings, this analysis did not use the mean levels of selfreported behavior in a classroom as an indicator of classroom composition but rather considered the proportion of classmates displaying antisocial behavior as perceived by individual students (for details on the peer nomination methodology, see the Measurement section). This approach specifically considers adolescents' own observations of their classrooms and relates to Bronfenbrenner's (1979) claim that individuals are most likely to be influenced by what they consider true and relevant. This suggestion is supported by empirical studies on, for example, substance use showing higher effects of perceived than actual peer behavior on individual behavior (Iannotti \& Bush, 1992).

\section{The Impact of the Behavior of Socially Dominant Students and Friends}

Besides the group of all students from a classroom, adolescents perceived as socially dominant may exert specific influence on other students' antisocial behavior development. Social dominance in the early adolescent years is characterized by being socially central and having the ability to control social resources such as influence and attention (e.g., Hawley, 1999; Jonkmann, Trautwein, \& Lüdtke, 2009). This social position is often considered to be achieved via both cooperative and coercive strategies and thus has many overlaps with the concept of perceived popularity (Hawley, 2003; Cillessen \& Rose, 2005). Because deviance can be a means to build social dominance and reputation among one's peers (Jonkmann et al., 2009), adolescents may imitate antisocial behavior by such classmates to obtain social reinforcement. Further, the observed proportion of dominant students with antisocial behavior may serve as a general marker of the norms regarding such behavior in the classroom. For example, Dijkstra, Lindenberg, and Veenstra (2008) examined the concept of perceived 
popularity, which is similar to social dominance. They reported a "popularity-norm effect" showing that bullying was unlikely to result in peer rejection in classrooms with popular adolescents who displayed high levels of bullying behavior.

Similar to the link between social dominance and influence, friendship is related to peer influence. In this regard, school is a major resource for building friendship networks (Kiesner, Poulin, \& Nicotra, 2003). Many studies examined friends' influence on individual antisocial behavior leaving it open to adolescents to nominate friends from school or other contexts (e.g., Espelage, Holt, \& Henkel, 2003; Warr \& Stafford, 1991; Morgan \& Grube, 1991). However, sizeable research has also focused specifically on the friends from the classroom. These studies mostly found that befriended classmates influence each others' levels of antisocial behavior (e.g., Powers et al., 2013; Vitaro, Brendgen, \& Tremblay, 2000). This effect is partly explainable by the high rates of common interaction between friends (Berndt, 2002) going along with many occasions for observational learning. Further, due to their social closeness, friends may specifically attend to the others' positive or negative evaluations of their own behavior. Finally, research suggests that to minimize conflict within friendship groups and to avoid individual rejection, group members are often willing to adapt to the friends' behaviors even when it contradicts their own attitudes (for overviews, see Warr, 2002; Rees \& Pogarsky, 2011).

\section{Differential Effects of Peer Subgroups}

Based on the literature, we expected that all three groups - entire classroom, socially dominant students, and friends - would influence the individual development of antisocial behaviors. However, it is less clear how the impacts of these groups relate to each other. Generally, the sparse number of studies examining the influence of different peer groups within one sample (e.g., represented as separate main effects in a statistical model) shows that peer subgroups can have unique impacts on individual antisocial behavior. This was found, for example, 
when considering both the influences of friends in class and the entire classroom (Powers et al., 2013; Müller, Begert, Hofmann, \& Studer, 2013) or the impacts of friends from in- and from out-of-school (Kiesner, Poulin, \& Nicotra, 2003). Even so, it is more difficult to deduct hypotheses on differences in the strength of peer subgroups' influence within classrooms. A review by Borsari and Carey (2001) suggests, for example, that perceived friends' behaviors and norms regarding alcohol use are more predictive of individual consumption than those perceived among "other" or "typical" college students. Similarly, Morgan and Grube (1991) found that perceived friends' substance use was a better predictor of individual consumption than the perception of what "most young people of my age" do. Although these studies did not focus on classrooms, their results may favor the hypothesis that friends from class exert more influence on antisocial behaviors than other peer subgroups in the class.

However, certain theoretical considerations also contradict the claim of a superior role of friends' influence. For example, avoiding mockery among peers is a main reason why adolescents do things they do not actually want to do (Warr, 2002). Such processes may be more present in the large group of the classroom than in the small circles of friends (Rees \& Pogarsky, 2011). This is even more complicated when considering the role of socially dominant students who may particularly guide the norms of who is mocked and which behavior will be reinforced in the classroom. In our view, it is thus only possible to state the general hypothesis that all three subgroups exert influence on individual aggressive, delinquent, and disruptive classroom behavior. The one exception regarding differential subgroup effects may be disruptive classroom behavior - we expect the most influential group to be the entire class. This is because only this type of behavior (by definition) is exhibited in the classroom with all classmates present. The level of disruptive classroom behavior among all classmates may thus be a stronger predictor of individual disruptive behavior development than the level of such behavior among the dominant and befriended peers. 


\section{The Current Study}

Previous research has usually either considered the impact of the entire classroom, dominant students, or friends on adolescent development. In contrast, we wanted to compare the extent of their influence within a single sample of early adolescents. For this purpose, a short-term longitudinal design was employed including four time points across students' first year in Swiss lower secondary schools. On the first occasion, students had just transitioned to secondary school and were assigned to a new classroom, which provided a novel peer environment. Class composition remained the same throughout the school year as students attended self-contained classrooms throughout nearly all of their courses (except for, e.g., weekly one-hour lessons in religion/ethics).

To obtain valid estimations of the net effects of classmates' perceived antisocial behavior on individual behavioral development, several control variables that often correlate with antisocial behavior were included in the analyses. We controlled for variables that could be attributed to individual students such as gender, socio-economic status, immigration background, perceived parental support, impulsivity, and school grades (e.g., Furlong, Morrison, \& Jimerson, 2004). Further, at the classroom level, the academic track to which students had been assigned and the aggregate perceived care displayed by the teacher were considered (e.g., Tsai \& Cheney, 2012; Van Houtte \& Stevens, 2008). To draw conclusions regarding the influence of the perceived behavior of classmates (and not any other peers) on individual behavior, we included the perceived behavior of the participating students' friends outside of class as a control variable (e.g., Ingoldsby \& Shaw, 2002).

\section{Method}

\section{Participants}

The present research was part of the "Fribourg Study on Peer Influence in Schools" investigating the social development among students in lower secondary schools. The 
analyses were conducted on Grade 7 students (age in years at T1: $M=13.12, S D=0.48$ ). Data were collected among students commencing with secondary school education after completing Grade 6 in the Swiss canton of Fribourg. The first time point was four weeks after the beginning of the school year after the students had supposedly built social networks (T1: Sept.; T2: Nov./Dec.; T3: Feb./Mar.; and T4: May/June). The sample was based on a complete data collection with participating students from all eight schools and 55 classrooms of the German-speaking region of the canton (others speak French). Student populations - in terms of absolute number - changed slightly across the school year, which was related to new entries or departures. Due to the support provided by the school authorities, participation rates were high (T1: $96.9 \%$ out of $n=828 ;$ T2: $97.6 \%$ out of $n=826$; T3: $95.5 \%$ out of $n=821$; and T4: $96.3 \%$ out of $n=821$ ) and 723 students participated at all four occasions. A total of 825 students took part in the study in at least one of the four data collections and was included in the later on described multilevel analyses. The school system comprised three standard academic tracks (advanced: Progymnasium; general: Sekundarschule; and basic: Realschule) and provided special education classrooms to students with learning difficulties.

\section{Measurement Instruments}

Dependent variables: self-reported antisocial behaviors. To assess aggressive and delinquent behaviors, the German Fribourg Self- and Peer-Report Scales - Antisocial Behavior (FSP-A; Müller, 2013) were applied. Only the instrument's self-report scales were used in this study. Generally, such anonymous self-reports are a well-established method for measuring antisocial behavior from the perspective of adolescents (Thornberry \& Krohn, 2000). In the FSP-A, students reported how many days within the previous 14 days they had exhibited a specific behavior (not restricted to the school setting). The short assessment intervals allowed repeated measurements across the school year and reduced memory bias. The FSP-A contains a 9-item subscale (Cronbach's $\alpha=.84$ ) measuring aggression, which 
included direct (e.g., hitting, pushing around, threatening, annoying, or insulting others) and indirect (e.g., spreading rumors about others or playing individuals off against one another) forms of aggression as well as oppositional behavior (e.g., arguing fiercely with others or being very angry). The delinquency subscale ( 11 items; $\alpha=.89$ ) considers a broad spectrum of behaviors such as carrying a weapon, consuming alcohol or drugs, public vandalism, destroying other people's property, threatening others, theft, or withholding fares when using public transport.

The FSP-A self-reports were evaluated among a sample of 552 students in grades 7-9 (Müller, 2013). The findings supported the theoretical structure (aggression vs. delinquency) of the scales using factor analysis. Further, the classroom aggregates obtained on the selfreports ("How often did you do that in the last 14 days?") correlated highly with the classroom aggregates obtained on the peer reports ("How many of your classmates did that in the last 14 days?"; aggression: $r=.79 ; p<.001$; delinquency: $r=.85 ; p<.001$ ). Moreover, the classroom means obtained on the self-reports significantly correlated with teachers' perceptions of the global level of psychosocial difficulties in the classrooms (aggression: $r=$ $.58 ; p<.001 ;$ delinquency: $r=.56 ; p<.001)$.

For the assessment of disruptive classroom behavior, the Fribourg Self- and PeerReport Scales - School Problem Behavior (FSP-S; Müller, Begert, Gmünder, \& Huber, 2012) were conducted. Again, only the instrument's self-report scales were used in this study. By responding to eight items, the students reported on the frequency of days with behaviors such as heckling during lessons, talking back to the teacher, cheating on a test, standing up in the classroom when not permitted, or engaging in non-academic activities during lessons in the past 14 days. Factor and reliability analyses indicated that the scale has a one-factor structure and a Cronbach's alpha of .83 in a sample of 627 students in grades 7-9. The classroom aggregates obtained on the self-reports correlated highly with the classroom aggregates obtained on the peer reports $(r=.92 ; p<.001$; similar instructions to those of the FSP-A). 
This indicated that the instrument is valid. In accordance with the procedure described by the authors of the FSP-A and the FSP-S, the values for each item in each scale were added to create global aggression, delinquency, and disruptive classroom behavior scores (Müller, 2013; Müller et al., 2012).

Independent variables: proportion of classmates exhibiting antisocial behavior. The behavioral characteristics of the different groups of students (all the students in a given classroom, dominant students, and friends) were operationalized as the individually perceived proportions of classmates forming part of these groups who display aggressive, delinquent, or disruptive classroom behavior. For this purpose, a two-step procedure with different peer nominations was applied. First, we assessed the behavior of the classmates as perceived by the individual students. The item measuring aggressive behavior was, "Who in your class offended others on at least one of the past 14 days?" As a measure of delinquency, students reported on who engaged in unauthorized activities and, as a measure of disruptive classroom behavior, the students reported on who disrupted lessons in the classroom.

This information enabled us to determine the individually perceived proportion of students in the specified three subgroups in the second step. For example, with regard to the proportion of aggressive students among all the classmates, a student may have reported seven classmates on the item, "Who in your class offended others on at least one of the past 14 days?" The number of nominations was then divided by the total number of classmates and multiplied by 100 to give a percentage of students individually perceived as showing aggressive behavior in the classroom.

With regard to the proportion of dominant students who were exhibiting antisocial behavior, the students nominated classmates in response to the item, "Who has the most say in your class?" This item enabled valid identification of socially dominant students. Individual nominations by each participating student were then compared to the corresponding nominations of students with perceived antisocial behavior. For example, if a student reported 
that three students have the say in class and further nominated two of them as having aggressive behavior, we concluded that this student perceived $66.7 \%$ of the dominant classmates as exhibiting aggression.

Friends were assessed with the item, "With whom in your class do you spend most of your time at school?" We chose an item focusing on the frequency of interaction based on meta-analytic results from Newcomb and Bagwell (1995), who reported a strong relationship between friendship and frequency of social interaction. A similar procedure to the one described above was used to define the proportion of befriended students who exhibited antisocial behavior. The number of peer nominations for each group was unlimited. Students could not nominate themselves.

Control variables. A rough estimation of the participants' immigration background was obtained through self-reported information on whether the participants owned a foreign passport (possibly in addition to a Swiss passport). Socio-economic status was estimated via the International Socio-Economic Index of Occupational Status classification (ISEIclassification; Ganzeboom \& Treiman, 1996). When both parents' occupations were reported, the higher employment score of the two was used. Data relating to the participants' levels of impulsivity were collected through the German self-report Impulsivity subscale of the Inventory to Assess Impulsivity, Risk Tolerance and Empathy in 9 to 14-Years-Olds (Stadler, Janke, \& Schmeck, 2004). The scale consists of 16 items measuring different aspects of cognitive and motivational impulsivity (e.g., "I often do and say things without thinking"), the presence of which had to be indicated with a Yes or No answer. For all analyses, the mean obtained on the scale was used $(\alpha=.79)$.

To assess the behavior of three best friends outside of class, the participants reported how often these anonymous friends "offend other people" (regarded as aggression) and "engage in unauthorized activities" (regarded as delinquency). Based on these ratings $(0=$ Never or Almost never, 1 = Sometimes, and 2 =Almost always), the mean was calculated for 
each scale (aggression: $\alpha=.65$; delinquency: $\alpha=.71$ ). The less satisfactory Cronbach's Alpha regarding aggression may relate to the small number of items and to out-of-class friends' heterogeneous levels of aggressive behavior. Because there was no available measure assessing the disruptive classroom behavior of out-of-class friends (students could not know this behavior as they attended a different classroom), the item "engage in unauthorized activities" was used instead. This appeared sensible because while disruptive classroom behavior clearly is less consequential than engaging in unauthorized activities, both behaviors concern the violation of rules - research shows close relationships between disruptive classroom behavior and more serious antisocial acts (Tillmann, Holler-Nowitzki, Holtappels, Meier, \& Popp, 2000).

Parental support regarding school-related issues was assessed through a four-point Likert scale ranging from Not true to Absolutely true developed by Fuchs, Lamnek, Lüdtke, and Baur (2009). The scale consisted of eight items, such as, "My parents pay attention to whether I do my homework" or "My parents almost always attend parent-teacher conferences"; the mean was calculated $(\alpha=.79)$ on the basis of scores on these items. In T4, the self-reported, expected means of the students' final grades in the three main subjects, German, French, and mathematics were used to estimate their grades. Perceived care by the teacher was based on the classroom aggregates obtained on the self-report scale Teacher Care, which forms part of a German scale called the Landau Scales of Social Climate (Saldern \& Littig, 1987). In this eight-item scale, respondents used a four-point Likert scale to estimate the extent to which they perceived their classroom teacher as supportive and solicitous. The response options ranged from Not true to Absolutely true (e.g., "Our teacher helps us like a friend would"). The subscale used was a slightly adapted version of Schwarzer and Jerusalem's (1999) scale with an internal reliability of $\alpha=.84$.

\section{Procedures}


Students and parents were informed about the study in written form. It was emphasized that participants would be completely anonymous and would not provide their names; in addition, any individual data would be in the possession of the research team. Students and their parents could withdraw participation from the study at any time. Participating students anonymously completed the questionnaires in their classrooms. All of the instructions, including detailed explanations of the questionnaires prior to completion thereof, were provided by trained research assistants according to the questionnaire manual. Mobile blinds (about $60 \mathrm{~cm}$ high) were placed between the participants to facilitate independent responses to the questions as best as possible. Individual and peer nomination data were processed on the basis of codes that remained the same across the four time points (i.e. students provided information on their dominant writing hand at each occasion, whether they have older siblings, etc.). As a result, even the research team could not identify the participants although they were able to follow individual trajectories over time.

\section{Statistical Analyses}

Initial consideration of the data characteristics indicated that the dependent variables in this study (number of days a person exhibits antisocial behavior) represented count data. Because antisocial behavior is rather uncommon, a right-skewed distribution is typically found in such measurements with variances exceeding the means (i.e., overdispersion; see also Childs, Sullivan, \& Gulledge, 2011). Similar results were found for the raw data of all three dependent variables in the present study (e.g., aggression at T1: skewness $v=3.95 ; M=0.46$; $S D=0.80$; Shapiro-Wilk test: $p<.01$ ) and their residuals (e.g., aggression at T1: $v=3.62$; Shapiro-Wilk test: $p<.01)$ across all time points. Hence, for inferential statistics, negative binomial models (a subgroup of Poisson models) that considers these data specificities were performed (Hilbe, 2008a). Moreover, the multilevel structure of the data had to be considered (Raudenbush \& Bryk, 2002). Time in weeks after T1 (Level 1) was nested in individuals 
(Level 2) who were nested in classrooms (Level 3). Because only eight schools took part in this study and there was no significant variance in antisocial behaviors between schools $(p>$ $.05)$, no fourth school level was included (Maas \& Hox, 2005). Multilevel analyses were performed with the software MLwiN 2.26 which uses maximum-likelihood estimation (IGLS) to account for unbalanced data due to missingness at one or more occasions (Rasbash, Charlton, Browne, Healy, \& Cameron, 2009).

There are some peculiarities about these types of analyses; for instance, Level 1 variance in negative binomial models is not a freely-estimated parameter but is fixed to 1 . Therefore, the variance explained by the predictors $\left(R^{2}\right)$ cannot be calculated. The use of pseudo- $R^{2}$ s was not considered to be a suitable alternative because such parameters are not equivalent to $R^{2}$, but rather represent measures of model fit. Further, different calculations of pseudo- $R^{2}$ s yield different results and there is no clear indication regarding which of those is suitable for use (e.g., Long, 1997). Thus, in negative binomial models, the effects are typically interpreted in terms of incidence rate ratios (IRRs) that represent the multiplicative change of the dependent variable for each one-unit change in the predictor (Hilbe, 2008b). The IRR is defined as the inverse logarithm of the coefficients (exponential function).

Longitudinal, multilevel negative binomial models were performed to address the research question presented here (Singer \& Willett, 2003). To avoid reciprocal causation, the scores of the three measures of aggressive, delinquent, and disruptive behavior among individuals across time (T2, T3, and T4) were predicted by the perceived proportion of classmates with antisocial behavior who belonged to the above-described groups at $\mathrm{T} 1$. Furthermore, we determined whether the three groups of students differed significantly in terms of their explanatory power regarding individual development. We therefore compared the fit of the three models to the data for each behavioral domain using Vuong's test (1989) for comparison of non-nested models (applying the software R 2.15.1). 


\section{Results}

Preliminary analyses.

Sample characteristics. Table 1 presents descriptive statistics of the participants' socio-demographic characteristics and key variables. Gender was nearly equally distributed, and the sample's mean socio-economic status was comparable to that of the overall population of Swiss students. About a fifth of the students had an immigration background (i.e., only a foreign passport or both a foreign and a Swiss passport). Of these, 9.5\% reported having only a foreign passport versus the national percentage of $22.5 \%$ (Federal Agency of Statistics, 2013). The participants' characteristics, in addition to the fact that Fribourg is a rural region of Switzerland (with only one school in a town consisting of more than 10,000 inhabitants), may be associated with lower levels of antisocial behavior than those generally exhibited by young adolescents in Switzerland. However, these discrepancies should not affect the validity of the results relating to the effects of peers' behavior on students' outcomes.

$<$ Insert Table 1 about here $>$

Subgroups of students and frequencies of antisocial behaviors. A mean of $6.1 \%(S D$ $=10.8$ ) of the students were identified to be dominant (having the most say in class) in relation to all the students in their class. A mean of $18 \%(S D=13.9)$ were identified as friends (people with whom the participants spent most of their time at school). The participating students nominated $8.6 \%$ of their classmates both as friends and as dominant; in addition, $27.2 \%$ of the classmates who were nominated as dominant were also nominated as friends. Table 2 shows the perceived proportions of students in the different student groups who exhibited antisocial behaviors at T1. For example, a mean of $13 \%$ of all students in the 
classroom were nominated as having been aggressive on at least one day within the previous 14 days (aggression column). In contrast, among the students perceived as dominant, $36.6 \%$ were considered to exhibit aggressive behavior. Bonferroni-corrected Wilcoxon tests were used to avoid Type I errors caused by multiple comparisons. This indicated that all betweengroup differences regarding the proportion of students exhibiting antisocial behaviors were significant $(p<.05)$ with the exception of the differences between classmate and friend delinquency. The results also showed within-group differences $(p<.01)$ with regard to displays of aggression and delinquency, respectively, and delinquency and disruptive classroom behavior. There was no difference between aggression and disruptive classroom behavior.

$<$ Insert Table 2 about here $>$

Correlations. As shown in Table 3, the correlations between the perceived proportions of classmates with antisocial behaviors at $\mathrm{T} 1$ and future individual behavior varied from low to moderate and were always significant $(p<.01)$. The higher the perceived proportion of classmates with antisocial behavior at the beginning of the school year, the higher the level of antisocial behavior reported by participating students later on.

$<$ Insert Table 3 here $>$

Hypothesis testing. With regard to the impact of classmates on aggression development among participating students, the results of the multilevel analyses (Table 4) indicate that the perceived proportion of classmates with aggressive behavior within all three groups of students significantly predicted the development of individual aggression. The IRR of 1.014 in Model 1 (all classmates) indicates that there was a $1.4 \%$ increase in aggressive 
individual behavior for each one-unit increase in the predictor variable (i.e., $1 \%$ more students in the class are regarded to have aggressive behavior). This accounts for the impact of the control variables. With regard to the effects of the perceived proportion of aggressive students in the other two subgroups, there were increases of $0.2 \%$ (dominant students) and $0.5 \%$ (friends) in individual aggressive behavior for each one unit increase in the predictors.

In terms of the impact of the control variables on individual aggressive development, we found a significant effect of time that indicated a decrease in aggressive behavior over time (T2-T4) in all three models. However, it is worth noting that individual behavior at T1 was not represented in the model and that the predictors may have affected the time coefficient. This means that the result does not represent absolute behavioral change over the entire school year. Furthermore, high incidences of individual impulsivity and perceived level of aggressive behavior among the out-of-classroom friends predicted an increase in individual aggression, while more parental support predicted a reduction. There were no effects of academic track and teacher support. Significant variations were found between individuals (Level 2) with regard to the mean of aggression (intercept) and change (slope) over time. The negative covariance between the intercept and the slope indicates that those with high aggression levels at the beginning of the school year exhibited a more marginal ascent over time than those who had initially exhibited less aggressive behavior.

$<$ Insert Table 4 about here $>$

Table 5 presents delinquency results. In contrast to the aggression domain, we found no effect of the perceived proportion of classmates with delinquent behavior among any of the three groups on individual delinquent development. Further, there was no change in individual delinquency between T2 and T4. In Models 1 and 3, delinquency was more prominent among boys than girls. Impulsivity and delinquent behavior among out-of-school 
friends and parental support were significant predictors in all three models; trends regarding the effects were similar to those found for aggression. Attending a high-qualifying track was related to less delinquency versus attending a low-qualifying track. When the reference category was changed in Model 3, it became clear that students in the high-qualifying track reported less delinquency than did those in the intermediate track $(p<.05 ; \operatorname{IRR}=0.595)$ and those in the special education classrooms $(p<.05 ; \operatorname{IRR}=0.312)$. With regard to variance, time varied significantly across individuals (Models 1 and 3). This indicates that students differed in their individual changes in delinquent behaviors across the school year. Further, classrooms differed significantly from each other in terms of the mean of delinquency (Model 2).

$<$ Insert Table 5 about here $>$

The development of disruptive classroom behavior among individuals was significantly predicted by the perceived proportion of disruptive classmates in all the groups of students identified in this study (see Table 6). The IRR of 1.001 in Model 1 (all classmates) indicates that there was a $1 \%$ increase in disruptive individual behavior for each one-unit increase in the predictor variable (i.e., $1 \%$ more students in the class are regarded as exhibiting disruptive behavior) - this accounts for the control variables. With regard to the effects of the perceived proportion of disruptive students in the other two subgroups, there were increases of $0.2 \%$ (popular students) and $0.4 \%$ (friends) in individual disruptive behavior for each one unit increase in the predictors.

The level of disruptive behavior did not change significantly between T2 and T4. Some models indicated that boys reported more disruptive behavior than girls did. In Model 3, higher scores of "engaging in unauthorized activities" among the out-of-classroom friends were associated with higher incidences of individual disruptive behavior. In all three models, 
more impulsivity, a higher socio-economic status, and less parental support were related to more disruptive behavior. The effect of a higher socio-economic status predicting more disruptive behavior may have been expected in the opposite direction. Further analyses showed that the correlations between socio-economic status and disruptive behavior across the time points were small ( $r=.07-.14)$ with only some of the correlations demonstrating significance. Furthermore, there was a significant variation at the individual level with regard to the intercept and the extent of change in behavior. The negative covariance indicates that those with higher disruptive behavior at the beginning of the school year had a more marginal ascent over time than did those who had initially exhibited such behavior to a lesser extent. Furthermore, we found a significant variation between classrooms in regards to the mean disruptive behavior.

$<$ Insert Table 6 about here $>$

Finally, we tested whether the perceived proportion of all the classmates, popular students, and friends with antisocial behavior differed in terms of the explanation power related to individual behavior. The results of Vuong's tests, as shown in Table 7, indicate no significant differences between the model fits. This suggests that the perceived proportion of students with antisocial behavior in all three groups predicted individual development to a similar degree.

$<$ Insert Table 7 about here $>$

\section{Discussion}

This study contributes towards a better understanding of the relationships between the perceived characteristics of different groups of classmates and students' development across 
several domains of antisocial behavior. We discuss the findings in relation to the characteristics of the different subgroups before turning to the differences found between behavioral domains and the implications thereof.

\section{Effects of the Different Subgroup Characteristics}

Regarding the effect of the entire classroom, the results of the current study are consistent with those of earlier research indicating that the mean classroom level of aggressive and disruptive behavior significantly predicts individual development (e.g., Kellam et al., 1998). Previous investigations mostly used teachers' judgments or students' self-reports to measure the effects of classroom composition. This study replicated these findings using a proportion score based on peer nominations and found an effect of perceived peer characteristics on behavioral development.

Furthermore, individual aggressive and disruptive behavior development was predicted by the perceived behavior among the socially dominant students in class. On the one hand, the characteristics of this group may have directly influenced individuals via social learning or students' fear of rejection by these adolescents. On the other hand, earlier findings indicate that dominant students significantly contribute to the definition of the prevailing classroom norms (e.g., for the group of perceived popular students, see Dijkstra et al., 2008). Hence, the impact of dominant adolescents may have also been mediated by the classroom norms. Besides that, it is interesting to note that participants estimated antisocial behavior to be highest among dominant adolescents versus all classmates and friends. This is in line with research reporting increased levels of rule breaking behavior among socially dominant students (Jonkmann et al., 2009).

Considering the third subgroup of classmates, it was found that the perceived proportion of friends from class with aggressive and disruptive behavior predicted adolescents' behavioral development. This corresponds with previous peer influence 
investigations (Morgan \& Grube, 1991; Powers et al., 2013; Vitaro et al., 2000). In extending these studies, it became evident that friends from the classroom have a unique influence on individuals that is beyond the perceived out-of-class friends' behavior (see also Müller et al., 2015). Taking a closer look at the impact of out-of-class friends, the perceived characteristics of these adolescents not only predicted students' individual aggression and delinquency but also their disruptive classroom behavior. This is noteworthy because disruptive classroom behavior by definition only occurs when friends from out-of-class are not present. Hence, students' behavior in the classroom setting appears to be influenced by peer experiences made both in the classroom and during extracurricular activities.

Interestingly, the perceived characteristics of all the classmates, dominant students, and friends explained individual behavior variance to a similar degree. This was also the case for disruptive behavior in the classroom, which we expected to be most influenced by the entire classroom. It can thus be concluded that even in situations where the large group of all classmates is present, individual social networks and roles of students in class appear to matter for individual students' behavior. Despite the effect similarities, there might be distinct reasons as to why students perceived each groups' behavior as salient. The characteristics of the entire classroom might provide important information for adolescents with regard to what is considered the "normal" level of aggressive and disruptive behavior among early adolescents (Cialdini et al., 1990). In contrast, dominant students may be convincing role models whose significance also stems from their coercive influence strategies. Among friends, social closeness and the amount of time spent together may foster reciprocal influence.

\section{Differences Between Behavioral Domains}

Thus far, all the findings indicate that classmates' perceived behavioral characteristics influence their peers' aggressive and disruptive behavior. In contrast, the perception of the 
classmates' behavior appeared to not affect students' delinquent behavior development. This contradicts, for example, a recent cross-sectional study that used classroom aggregates based on self-reported marijuana consumption as a predictor of individual consumption (Araos et al., 2014). Even more surprising, the results are at odds with findings from our earlier analyses using the same sample but measuring classroom composition with aggregated selfreports of peers (Müller et al., 2015). The different results obtained from these two analyses of the same participants may shed light on certain methodological issues.

It is generally quite surprising that the analyses in the current study that used perceived peer characteristics resulted in non-significant effects, while those using aggregated self-reports of peers as an indicator of class composition were significant. This is because one might expect the correlation between self-reported behaviors and perceived peer behaviors to be higher when reported by the same individual than when reported by different persons (Henry, Kobus, \& Schoeny, 2011). Hence, it is probable that the contradictory results between the two analyses are largely due to the different items used to characterize peers' delinquency. In the earlier analysis, all students completed the comprehensive 11-item self-reported delinquency scale of the FSP-A as described in the Methodology section. The peers' behavior was then operationalized as the classroom aggregate of the scores obtained on the scale; however, in the current study, students nominated their classmates based on only one superordinate item (i.e., "engage in unauthorized activities"), which is less specific. Further, peer reports at the beginning of the school year may have been less sensitive than the selfreports in this study because delinquency often occurs outside of school and, at the time, students might not have known each other well enough to judge this. This concern may be less applicable to other antisocial behaviors such as classroom disruptions, which are easier for students to identify. Based on the above, the results obtained in this study regarding classmates' influence on delinquency should be interpreted cautiously and need to be further examined. 


\section{Practical Implications}

This study's findings point to the importance of considering classrooms as social systems in which not only the teacher but also the classmates influence students' behavioral development. In this regard, the results support recent suggestions to actively consider this perspective in teachers' daily instruction and interventions on antisocial behavior (e.g., Farmer, McAuliffe Lines, \& Hamm, 2011).

At the same time, the current findings lessen the hope that simple solutions can be applied at the peer level to reduce students' antisocial behavior. For example, the exclusion of a dominant adolescent with antisocial behavior from the classroom may not guarantee a positive change in the behavior of other students given the lasting significance of friends and the high probability that others with antisocial behavior may take the dismissed student's place. Further, even minor changes in class composition, social networks, or roles may affect individual students' behavior. Specific interventions on classroom peer ecology (e.g., changing seating positions, planned assignments of students to specific workgroups in the classroom) can thus be effective; however, sometimes they may also risk negative consequences (e.g., unintended changes in social roles of students) especially when being based on invalid teacher perceptions of the social networks in class (Gest, 2006; Neal, Cappella, Wagner, \& Atkins, 2011). An important research desiderate thus remains to further develop and evaluate classroom interventions that consider the complexity of classroom social systems involving both influences from teachers and peers.

\section{Limitations and Future Perspectives}

One of the strengths of this study lies in the short-term longitudinal design that provides insights from those directly involved in the peer ecology of classrooms. However, the focus on students' own perceptions, as provided in self- and peer reports, is both an 
advantage and a limitation because the two perspectives could be confounded. For example, Henry et al. (2011) observed a false consensus effect wherein adolescents' reports of their friends' substance use were biased in the direction of their own use. This concern may have been addressed to some extent in this study because perceptions of peers' characteristics (T1) and self-reported behavior (T2-T4) were not measured at the same time. Nevertheless, future studies should also analyze direct observations and behavior ratings provided by teachers or parents. A related issue is the fact that the group of socially dominant students was determined on the basis of students' individual perceptions. This is plausible because it represents the views of the influenced subjects. However, it would also be useful to apply other procedures such as identifying the most dominant students in a classroom according to the ratings provided by all of their classmates. Another point related to the peer nominations used for describing the subgroups' characteristics is that they depended on only one item per behavioral domain. As a consequence, nominations were rather general (e.g., "offend others") and could not represent the complete heterogeneity of the underlying concepts. Future studies may thus use multiple nominations to construct global behavior scores.

In our view, it will be a worthwhile endeavor to further examine the influence exerted by different subgroups of students in future studies. One of the problems met in observational studies investigating this issue is that the social groups within a classroom tend to overlap (e.g., in this study $27.2 \%$ of the classmates nominated as popular were also nominated as friends). This may mask differential effects and in future could be addressed through the use of experimental, computer-based studies using fictional peers whose social positions, relationships, and behaviors can be systematically manipulated. Such an approach could facilitate a comparison of the effects of these variables on specific behaviors among the subjects.

\section{References}


Akers, R. L. (2009). Social learning and social structure. A general theory of crime and deviance. Brunswick: Transaction.

Araos, C., Cea, M., Fernández, M., \& Valenzuela, E. (2014). The role of school context on marijuana use in Chile. A classroom-level analysis. Deviant Behavior, 35, 412-432.

Bandura, A. (1977). Social Learning Theory. Upper Saddle River: Prentice Hall.

Barth, J. M., Dunlap S. T., Dane, H., Lochmann J. E., \& Wells, K. C. (2004). Classroom environment influences on aggression, peer relations, and academic focus. Journal of School Psychology, 42, 115-133.

Berndt, T. J. (2002). Friendship quality and social development. Current Directions in Psychological Science, 11, 7-10.

Borsari, B. \& Carey, K. B. (2001). Peer influences on college drinking: A review of research. Journal of Substance Use, 13, 2001.

Bronfenbrenner, U. (1979). The ecology of human development: Experiments by nature and design. Cambridge, MA: Harvard University Press.

Childs, K. K., Sullivan, C. J., \& Gulledge, L. M. (2011). Delinquent behavior across adolescence: Investigating the shift in salience of key criminological predictors. Deviant Behavior, 32, 64-100.

Cialdini, R. B., Kallgren, C. A., \& Reno, R. R. (1990). A focus theory of normative conduct. Advances in Experimental Social Psychology, 24, 201-234.

Cillessen, A. H. N. \& Rose, A. J. (2005). Understanding popularity in the peer system. Current Directions in Psychological Science, 14, 102-105.

Dijkstra, J. K., Lindenberg, S., \& Veenstra, R. (2008). Beyond the class norm. Bullying behavior of popular adolescents and its relation to peer acceptance and rejection. Journal of Abnormal Child Psychology, 36, 1289-1299.

Dishion, T. J. \& Tipsord, J. M. (2011). Peer contagion in child and adolescent social emotional development. Annual Review of Psychology, 62, 189-214. 
Espelage, D. L., Holt, M. K., \& Henkel, R. R. (2003). Examination of peer-group contextual effects on aggression during early adolescence. Child Development, 74, 205-220.

Evertson, C. M. \& Weinstein, C. S. (Eds.). (2006). Handbook of classroom management. Mahwah: Lawrence Erlbaum.

Farmer, T. W., McAuliffe Lines, M., \& Hamm, J. V. (2011). Revealing the invisible hand. The role of teachers in children's peer experiences. Journal of Applied Developmental Psychology, 32, 247-256.

Federal Agency of Statistics. (Ed.). (2013). Migration und Integration. Ständige Wohnbevölkerung im Alter von 10 - 14 Jahren im Jahr 2011 mit Schweizer Pass. (Migration and integration. Permanent population aged $10-14$ in possession of the Swiss passport 2011). Retrieved June 62013 from: http://www.pxweb.bfs.admin.ch

Fuchs, M., Lamnek, S., Luedtke, J., \& Baur, N. (2009). Gewalt an Schulen. 1994 - 1999 2004 (Violence in schools. 1994 - 1999 - 2004). Wiesbaden: VS.

Furlong, M. J., Morrison, G. M., \& Jimerson, S. R. (2004). Externalizing behaviors of aggression and violence and the school context. In R. B. Rutherford, M. M. Quinn \& S. R. Mathur (Eds), Handbook of Research in Emotional and Behavioral Disorders (pp. 243261). New York: The Guilford Press.

Ganzeboom, H. B. G. \& Treiman, D. J. (1996). Internationally comparable measures of occupational status for the 1988 International Standard Classification of Occupation. Social Science Research, 25, 201-239.

Gest, S. D. (2006). Teacher reports of children's friendships and social groups: Agreement with peer reports and implications for studying peer similarity. Social Development, 15 , 248-259.

Hawley, P. H. (1999). The ontogenesis of social dominance: A strategy-based evolutionary perspective. Developmental Review, 19, 97-132 
Hawley, P. H. (2003). Prosocial and coercive configurations of resource control in early adolescence. A case for the well-adapted Machiavellian. Merrill-Palmer Quarterly, 49, 279-308.

Henry, D., Kobus, K., \& Schoeny, E. S. (2011). Accuracy and bias in adolescents' perceptions of friends' substance use. Psychology of Addictive Behaviors, 25, 80-89.

Hilbe, J. M. (2008a). Negative binomial regression. Cambridge: University Press.

Hilbe, J. M. (2008b). Brief overview on interpreting count model risk ratios. An addendum to Negative binomial regression. Cambridge: University Press.

Hill, N. E., Castellino, D. R., Lansford, J. E., Nowlin, P., Dodge, K. A., Bates, J. E., Pitt, G. S., et al. (2004). Parent academic involvement as related to school behavior, achievement, and aspirations: Demographic variations across adolescence. Child Development, 75, 14911509.

Hinduja, S. \& Patchin, J. W. (2008). Personal information of adolescents on the internet: A quantitative content analysis of MySpace. Journal of Adolescence, 31, 125-146.

Hinshaw, S. P. (1992). Externalizing behavior problems and academic underachievement in childhood and adolescence: Causal relationships and underlying mechanisms. Psychological Bulletin, 111, 125-155.

Huesmann, L. R. \& Eron, L. D. (1989). Individual differences and the trait of aggression. European Journal of Personality, 3, 95-106.

Iannotti, R. J. \& Bush, P. J. (1992). Perceived vs. actual friends' use of alcohol, cigarettes, marijuana, and cocaine: Which has the most influence? Journal of Youth and Adolescence, 21, 375-389.

Ingoldsby, E. M. \& Shaw, D. S. (2002). Neighborhood contextual factors and early-starting antisocial pathways. Clinical Child and Family Psychology Review, 5, 21-55. 
Jonkmann, K., Trautwein, U., \& Lüdtke, O. (2009). Social dominance in adolescence. The moderating role of the classroom context and behavioral heterogeneity. Child Development, 80, 338-355.

Juvonen, J. \& Galván, A. (2008). Peer influence in involuntary social groups. Lessons from research on bullying. In M. J. Prinstein \& K. A. Dodge (Eds.), Understanding peer influence in children and adolescents (pp. 225-244). New York: Guilford.

Kellam, S. G., Ling, X., Merisca, R., Brown, C. H., \& Ialongo, N. (1998). The effect of the level of aggression in the first grade classroom on the course of malleability of aggressive behavior into middle school. Development and Psychopathology, 10, 165-185.

Kiesner, J., Poulin, F., \& Nicotra, E. (2003). Peer relations across contexts: Individualnetwork homophily and network inclusion in and after school. Child Development, 74, $1328-1343$.

Loeber, R., White, H. R., \& Burke, J. D. (2012). Developmental sequences and pathways toward serious delinquency and substance use. In: T. Bliesener, A. Beelmann \& M. Stemmler (Eds.), Antisocial behavior and crime: Contributions of developmental and evaluation research to prevention and intervention (pp. 39-52). Cambridge: Hogrefe.

Long, J. S. (1997). Regression models for categorical and limited dependent variables. Thousand Oaks: SAGE.

Maas, C. J. M. \& Hox, J. J. (2005). Sufficient sample sizes for multilevel modeling. Methodology, 1, 86-92.

Mercer, S. H., McMillen, J. S., \& DeRosier (2009). Predicting change in children's aggression and victimization using classroom-level descriptive norms of aggression and pro-social behavior. Journal of School Psychology, 47, 267-289.

Moreno, M. A., Parks, M. R., Zimmerman, F. J., Brito, T. E., \& Christakis, D. A. (2009). Display of health risk behaviors on MySpace by adolescents: prevalence and associations. Archives of Pediatric and Adolescent Medicine, 163, 27-34. 
Morgan, M. \& Grube, J. W. (1991). Closeness and peer group influence. British Journal of Social Psychology, 30, 159-169.

Müller, C., Begert, T., Gmünder, L., \& Huber, C. (2012). The "Fribourg Self- and PeerReport Scales - School Problem Behavior" - Development and evaluation of an instrument to longitudinally assess disruptive behavior in the classroom. Empirische Sonderpädagogik, 4, 3-21.

Müller, C., Begert, T., Hofmann, V. \& Studer, F. (2013). Effekte der Klassenzusammensetzung auf individuelles schulisches Problemverhalten - Welche Rolle spielt das Verhalten der Gesamtklasse, der „Coolen“, der „Extremen“ und der persönlichen Freunde? (Effects of classroom composition on individual school problem behavior What is the role of the entire classroom, „cool" students, most deviant students and friends?). Zeitschrift für Pädagogik, 5, 722-742.

Müller, C., Hofmann, V., Fleischli, J. \& Studer, F. (2015). Effects of classroom composition on the development of antisocial behavior in lower secondary school. Journal of Research on Adolescence (online early view).

Müller, C. (2013). Assessing antisocial behaviour and attitudes in longitudinal research Development and evaluation of the "Fribourg Self- and Peer-Report Scales - Antisocial Behavior“. Heilpädagogische Forschung, 39, 2-13.

Morgan, M. \& Grube, J. W. (1991). Closeness and peer group influence. British Journal of Social Psychology, 20, 159-169.

Neal, J. W., Cappella, E., Wagner, C., \& Atkins, M. S. (2011). Seeing eye to eye: Predicting teacher-student agreement on classroom social networks. Social Development, 20, 376393.

Newcomb, A. F. \& Bagwell, C. L. (1995). Children's friendship relations: A meta-analytic review. Psychological Bulletin, 117, 306-347. 
Nock, M. K., Kazdin, A. E., Hiripi, E., \& Kessler, R. C. (2006). Prevalence, subtypes, and correlates of DSM-IV conduct disorder in the National Comorbidity Survey Replication. Psychological Medicine, 36, 699-710.

Powers, C. J., Bierman. K. L., \& Conduct Problems Research Group (2013). The multifaceted impact of peer relations on aggressive-disruptive behavior early elementary school. Developmental Psychology, 49, 1174-1186.

Rasbash, J., Charlton, C., Browne, W.J., Healy, M., \& Cameron, B. (2009). MLwiN Version 2.1. Bristol: University of Bristol.

Raudenbush, S. \& Bryk, A. (2002). Hierarchical linear models: Applications and data analysis methods. Thousand Oaks: Sage.

Rees, C. \& Pogorsky, G. (2011). One bad apple may not spoil the whole bunch: Best friends and adolescent delinquency. Journal of Quantitative Criminology, 27, 197-223.

Saldern, M. \& Littig, K. E. (1987). Landau scales to assess the social climate (Landauer Skalen zum Sozialklima). Weinheim: Beltz.

Schwarzer, R. \& Jerusalem, M. (Eds.). (1999). Scales to assess teachers' and students' characteristics. (Skalen zur Erfassung von Lehrer- und Schülermerkmalen). Retrieved July 72013 from www.psyc.de/skalendoku.pdf.

Singer, J. D. \& Willett, J. B. (2003). Applied longitudinal data analysis. Modeling change and event occurrence. New York: Oxford University Press.

Stadler, C., Janke, W., \& Schmeck, K. (2004). Inventory to assess impulsivity, risk tolerance and empathy in 9 to 14 years old children (Inventar zur Erfassung von Impulsivität, Risikoverhalten und Empathie bei 9- bis 14- jährigen Kindern). Göttingen: Hogrefe.

Thomas, D. E., Bierman, K. L., Powers, C. J., \& The Conduct Problems Prevention Research Group. (2011). The influence of classroom aggression and classroom climate on aggressive-disruptive behavior. Child Development, 82, 751-757. 
Thomas, D. E., Bierman, K. L., \& The Conduct Problems Prevention Research Group. (2006). The impact of classroom aggression on the development of aggressive behavior problems in children. Development and Psychopathology, 18, 471-487.

Thornberry, T. P., \& Krohn, M. D. (2000).The self-report method for measuring delinquency and crime. Criminal Justice, 4, 33-83.

Tillmann, K., Holler-Nowitzki, B., Holtappels, H., Meier, U., \& Popp, U. (2000). School violence as a school problem (Schülergewalt als Schulproblem ). Weinheim: Juventa.

Tsai, S. \& Cheney, D. (2012). The impact of the adult-child relationship on school adjustment for children at risk of serious behavior problems. Journal of Emotional and Behavioral Disorders, 20, 106-114.

Van Houtte, M. \& Stevens, P. A. J. (2008). Sense of futility. The missing link between track position and self-reported school misconduct. Youth Society, 40, 245-264.

Vile Junod, R. E., DuPaul, G. J., Jitendra, A. K., Volpe, R. J., \& Cleary, K. S. (2006). Classroom observations of students with and without ADHD: Differences across types of engagement. Journal of School Psychology, 44, 87-104.

Vitaro, F., Brendgen, M., \& Tremblay, R . E. (2000). Influence of deviant friends on delinquency: Searching for moderator variables. Journal of Abnormal Child Psychology, $28,313-325$.

Vuong, Q. H. (1989). Likelihood ratio tests for model selection and non-nested hypotheses. Econometrica, 57, 307-333.

Warr, M. \& Stafford, M. (1991). The influence of delinquent peers: What they think or what they do? Criminology, 29, 851-866.

Warr, M. (2002). Companions in crime. Cambridge: University Press. 
Table 1

Sample Characteristics

\begin{tabular}{llll}
\hline & Mean (SD) & $\%$ & Range \\
\hline Boys & - & 52.5 & - \\
Foreign Nationality $^{\mathrm{a}}$ & - & 9.5 & - \\
Immigration background $^{\mathrm{b}}$ & - & 21.8 & - \\
Socio-economic status $^{\mathrm{c}}$ & $49.22(16.05)$ & - & $20.00-85.00$ \\
Impulsivity $_{\text {Outside-of-class friends' aggression }}$ & $0.41(0.22)$ & - & $0.00-1.00$ \\
Outside-of-class friends' delinquency $_{\text {School grades }}$ & $0.51(0.47)$ & - & $0.00-2.00$ \\
Parental support & $5.00(0.47)$ & - & $0.00-2.00$ \\
High academic track & $2.47(0.44)$ & - & $3.17-6.00$ \\
Middle academic track & - & 28.7 & $0.00-3.00$ \\
Low academic track $_{\text {Special educational track }}$ & - & 41.7 & - \\
Teacher's support (aggregated in & - & 23.6 & - \\
classroom) & - & 5.9 & - \\
\hline
\end{tabular}

${ }^{a}$ Owns only a foreign passport. ${ }^{b}$ Owns a foreign passport (possibly in addition to a Swiss passport).

${ }^{\mathrm{c}}$ International Socioeconomic Index. 
Table 2

Perceived Proportions of Classmates Showing Antisocial Behaviors in Different Student Groups at T1

\begin{tabular}{|c|c|c|c|}
\hline Student group & Aggression & Delinquency & Disruptive \\
\hline $\begin{array}{l}\% \text { antisocial }{ }^{\mathrm{a}} \text { students } \\
\text { among all classmates }\end{array}$ & $13.0(16.0)$ & $6.4(13.1)$ & $13.5(15.7)$ \\
\hline $\begin{array}{l}\% \text { antisocial }{ }^{\mathrm{a}} \text { students in } \\
\text { the dominant subgroup }\end{array}$ & $36.6(43.5)$ & $18.6(35.5)$ & $34.8(42.6)$ \\
\hline $\begin{array}{l}\% \text { antisocial }{ }^{\mathrm{a}} \text { students in } \\
\text { the befriended subgroup }\end{array}$ & $13.9(28.7)$ & $7.5(22.8)$ & $12.8(27.3)$ \\
\hline
\end{tabular}

"The term "antisocial" relates to aggressive, delinquent or disruptive classroom behavior depending on the column considered 
Table 3

Spearman's Correlations Between the Perceived Proportions of Classmates Showing Antisocial Behaviors at T1, and Individual Behavior T1-T4

\begin{tabular}{|c|c|c|c|c|}
\hline $\begin{array}{l}\text { Individual perception } \\
\text { of the classmates at } \\
\mathrm{T} 1\end{array}$ & $\begin{array}{l}\text { T1 individual } \\
\text { aggression }\end{array}$ & $\begin{array}{l}\text { T2 individual } \\
\text { aggression }\end{array}$ & $\begin{array}{l}\text { T3 individual } \\
\text { aggression }\end{array}$ & $\begin{array}{l}\text { T4 individual } \\
\text { aggression }\end{array}$ \\
\hline $\begin{array}{l}\% \text { aggressive students } \\
\text { among all classmates }\end{array}$ & $.39^{* *}$ & $.33^{* *}$ & $.28^{* *}$ & $.24^{* *}$ \\
\hline \multirow{3}{*}{$\begin{array}{l}\% \text { aggressive students } \\
\text { among the dominant } \\
\% \text { aggressive students } \\
\text { among the friends }\end{array}$} & $.26^{* *}$ & $.20^{* *}$ & $.23^{* *}$ & $.20^{* *}$ \\
\hline & $.28^{* *}$ & $.24^{* *}$ & $.22^{* *}$ & $.24^{* *}$ \\
\hline & $\begin{array}{l}\text { T1 individual } \\
\text { delinquency }\end{array}$ & $\begin{array}{l}\text { T2 individual } \\
\text { delinquency }\end{array}$ & $\begin{array}{l}\text { T3 individual } \\
\text { delinquency }\end{array}$ & $\begin{array}{l}\text { T4 individual } \\
\text { delinquency }\end{array}$ \\
\hline \multirow{4}{*}{$\begin{array}{l}\% \text { delinquent students } \\
\text { among all classmates } \\
\% \text { delinquent students } \\
\text { among the dominant } \\
\% \text { delinquent students } \\
\text { among the friends }\end{array}$} & $.19^{* *}$ & $.15^{* *}$ & $.18^{* *}$ & $.14^{* *}$ \\
\hline & $.17^{* *}$ & $.18^{* *}$ & $.17^{* *}$ & $.10^{*}$ \\
\hline & $.24^{* *}$ & $.16^{* *}$ & $.20^{* *}$ & $.18^{* *}$ \\
\hline & $\begin{array}{l}\text { T1 individual } \\
\text { disruptive } \\
\text { behavior }\end{array}$ & $\begin{array}{l}\text { T2 individual } \\
\text { disruptive } \\
\text { behavior }\end{array}$ & $\begin{array}{l}\text { T3 individual } \\
\text { disruptive } \\
\text { behavior }\end{array}$ & $\begin{array}{l}\text { T4 individual } \\
\text { disruptive } \\
\text { behavior }\end{array}$ \\
\hline $\begin{array}{l}\% \text { disruptive students } \\
\text { among all classmates }\end{array}$ & $.24^{* *}$ & $.20^{* *}$ & $.18^{* *}$ & $.18^{* *}$ \\
\hline $\begin{array}{l}\% \text { disruptive students } \\
\text { among the dominant }\end{array}$ & $.14^{* *}$ & $.14^{* *}$ & $.12^{*}$ & .06 \\
\hline $\begin{array}{l}\text { \% disruptive students } \\
\text { among the friends }\end{array}$ & $.28^{* *}$ & $.25^{* *}$ & $.22^{* *}$ & $.20^{* *}$ \\
\hline
\end{tabular}
${ }^{*} p<.05 ; * * p<.01$ 
Table 4

Prediction of Individual Aggression (T2-T4) by the Perceived Proportion of Aggressive Classmates in Different Student Groups (T1) Using Longitudinal Multilevel Analyses

\begin{tabular}{lllllll}
\hline & Model 1: & \multicolumn{4}{l}{ Model 2: } & \multicolumn{2}{l}{ Model 3: } \\
& All classmates & & Dominant students & Friends & \\
\hline & Log- $B(S E)$ & $I R R$ & $\log -B(S E)$ & $I R R$ & Log- $B(S E)$ & IRR \\
\hline Intercept & $1.002(0.883)$ & 2.724 & $1.737(1.100)$ & 5.680 & $1.355(0.891)$ & 3.877 \\
\hline
\end{tabular}

Level 1: Time

\begin{tabular}{lllllll}
\hline Time in weeks since T1 & $-0.008^{*}(0.004)$ & 0.992 & $-0.008^{*}(0.004)$ & 0.992 & $-0.009^{*}(0.004)$ & 0.991 \\
\hline $\begin{array}{l}\text { Level 2: Individual } \\
\begin{array}{l}\text { Perceived proportion of } \\
\text { aggressive classmates in } \\
\text { student group }\end{array}\end{array}$ & $0.014^{* *}(0.003)$ & 1.014 & $0.002^{*}(0.001)$ & 1.002 & $0.005^{*}(0.002)$ & 1.005 \\
\hline Gender (girl) & $0.151(0.094)$ & 1.163 & $0.134(0.117)$ & 1.143 & $0.062(0.095)$ & 1.064 \\
\hline Immigration (no immigr.) & $-0.039(0.120)$ & 0.962 & $0.156(0.150)$ & 1.169 & $-0.020(0.120)$ & 0.980 \\
\hline Socio-economic status & $0.002(0.003)$ & 1.002 & $0.003(0.004)$ & 1.003 & $0.002(0.003)$ & 1.002 \\
\hline Impulsivity & $2.041^{* *}(0.227)$ & 7.698 & $1.614^{* *}(0.277)$ & 5.023 & $1.931^{* *}(0.226)$ & 6.896 \\
\hline $\begin{array}{l}\text { Outside-of-class friends' } \\
\text { behavior }\end{array}$ & $0.629^{* *}(0.105)$ & 1.876 & $0.745^{* *}(0.130)$ & 2.106 & $0.680^{* *}(0.105)$ & 1.974 \\
\hline School grades & $0.101(0.138)$ & 1.106 & $0.146(0.175)$ & 1.157 & $0.119(0.139)$ & 1.126 \\
\hline Parental support & $-0.369^{* *}(0.114)$ & 0.691 & $-0.433^{* *}(0.144)$ & 0.649 & $-0.384^{* *}(0.113)$ & 0.681 \\
\hline
\end{tabular}

Level 3: Classroom

\begin{tabular}{|c|c|c|c|c|c|c|}
\hline High academic track (low) & $-0.162(0.162)$ & 0.850 & $-0.224(0.211)$ & 0.799 & $-0.287(0.164)$ & 0.751 \\
\hline $\begin{array}{l}\text { Middle academic track } \\
\text { (low) }\end{array}$ & $-0.086(0.138)$ & 0.918 & $-0.173(0.179)$ & 0.841 & $-0.181(0.140)$ & 0.834 \\
\hline $\begin{array}{l}\text { Special educational track } \\
\text { (low) }\end{array}$ & $-0.357(0.255)$ & 0.700 & $-0.868^{*}(0.364)$ & 0.420 & $-0.217(0.265)$ & 0.805 \\
\hline $\begin{array}{l}\text { Teacher's support } \\
\text { aggregated in class }\end{array}$ & $0.352(0.193)$ & 1.422 & $0.087(0.249)$ & 1.091 & $0.280(0.195)$ & 1.323 \\
\hline \multicolumn{7}{|l|}{ Variance Components } \\
\hline $\begin{array}{l}\text { Variance intercept } \\
\text { between individuals }\end{array}$ & $1.301^{* *}(0.249)$ & 3.673 & $0.907^{* *}(0.237)$ & 2.477 & $1.276^{* *}(0.239)$ & 3.582 \\
\hline $\begin{array}{l}\text { Variance slope of time } \\
\text { between individuals }\end{array}$ & $0.001^{* *}(0.000)$ & 1.001 & $0.001^{* *}(0.000)$ & 1.001 & $0.002^{* *}(0.000)$ & 1.002 \\
\hline $\begin{array}{l}\text { Covariance intercept/slope } \\
\text { of time between } \\
\text { individuals }\end{array}$ & $-0.025^{* *}(0.009)$ & 0.975 & $-0.022^{*}(0.010)$ & 0.978 & $-0.027^{* *}(0.009)$ & 0.973 \\
\hline $\begin{array}{l}\text { Variance intercept } \\
\text { between classes }\end{array}$ & $0.116(0.081)$ & 1.123 & $0.126(0.112)$ & 1.134 & $0.090(0.074)$ & 1.094 \\
\hline $\begin{array}{l}\text { Variance slope of time } \\
\text { between classes }\end{array}$ & $0.000(0.000)$ & 1.000 & $0.000(0.000)$ & 1.000 & $0.000(0.000)$ & 1.000 \\
\hline $\begin{array}{l}\text { Covariance intercept/slope } \\
\text { of time between classes }\end{array}$ & $-0.005(0.003)$ & 0.995 & $-0.002(0.004)$ & 0.998 & $-0.003(0.003)$ & 0.997 \\
\hline
\end{tabular}

Note. Enclosed in parentheses: Reference category.

aStudent groups relate to "all classmates", "dominant students", or "friends" depending on the column considered

$* p<.05 . * * p<.01$. Significance-test results based on unrounded results. 
Table 5

Prediction of Individual Delinquency (T2-T4) by the Perceived Proportion of Delinquent Classmates in Different Student Groups (T1) Using Longitudinal Multilevel Analyses

\begin{tabular}{lllllll}
\hline & Model 1: & \multicolumn{4}{l}{ Model 2: } & \multicolumn{3}{l}{ Model 3: } \\
& All classmates & & Dominant students & Friends & \\
\hline & $\log -B(S E)$ & IRR & $\log -B(S E)$ & IRR & $\log -B(S E)$ & IRR \\
\hline Intercept & $0.920(1.563)$ & 2.509 & $4.345^{*}(1.857)$ & 77.092 & $1.565(1.613)$ & 4.783 \\
\hline
\end{tabular}

Level 1: Time

\begin{tabular}{|c|c|c|c|c|c|c|}
\hline Time in weeks since $\mathrm{T} 1$ & $0.012(0.008)$ & 1.012 & $0.005(0.009)$ & 1.005 & $0.013(0.008)$ & 1.013 \\
\hline \multicolumn{7}{|l|}{ Level 2: Individual } \\
\hline $\begin{array}{l}\text { Perceived proportion of } \\
\text { aggressive classmates in } \\
\text { student group }\end{array}$ & $0.002(0.007)$ & 1.002 & $0.004(0.003)$ & 1.004 & $0.000(0.004)$ & 1.000 \\
\hline Gender (girl) & $0.520^{* *}(0.172)$ & 1.682 & $0.190(0.199)$ & 1.209 & $0.448^{*}(0.176)$ & 1.565 \\
\hline Immigration (no immigr.) & $-0.405(0.219)$ & 0.667 & $-0.131(0.253)$ & 0.877 & $-0.397(0.223)$ & 0.672 \\
\hline Socio-economic status & $0.004(0.006)$ & 1.004 & $0.012(0.007)$ & 1.012 & $0.003(0.006)$ & 1.003 \\
\hline Impulsivity & $2.571^{* *}(0.415)$ & 13.079 & $2.466^{* *}(0.468)$ & 11.775 & $2.598^{* *}(0.424)$ & 13.437 \\
\hline $\begin{array}{l}\text { Outside-of-class friends' } \\
\text { behavior }\end{array}$ & $0.700^{* *}(0.192)$ & 2.014 & $0.616^{* *}(0.208)$ & 1.852 & $0.695^{* *}(0.201)$ & 2.004 \\
\hline School grades & $0.031(0.248)$ & 1.031 & $-0.399(0.295)$ & 0.671 & $-0.049(0.256)$ & 0.952 \\
\hline Parental support & $-0.903^{* *}(0.205)$ & 0.405 & $-1.051^{* *}(0.237)$ & 0.350 & $-0.952^{* *}(0.208)$ & 0.386 \\
\hline \multicolumn{7}{|l|}{ Level 3: Classroom } \\
\hline High academic track (low) & $-0.716^{*}(0.281)$ & 0.489 & $-0.838^{*}(0.379)$ & 0.433 & $\left.-0.796^{* *} 0.288\right)$ & 0.451 \\
\hline $\begin{array}{l}\text { Middle academic track } \\
\text { (low) }\end{array}$ & $-0.203(0.238)$ & 0.816 & $-0.307(0.324)$ & 0.736 & $-0.277(0.244)$ & 0.758 \\
\hline $\begin{array}{l}\text { Special educational track } \\
\text { (low) }\end{array}$ & $0.236(0.440)$ & 1.266 & $-0.916(0.677)$ & 0.400 & $0.370(0.465)$ & 1.448 \\
\hline $\begin{array}{l}\text { Teacher's support } \\
\text { aggregated in class }\end{array}$ & $-0.313(0.327)$ & 0.731 & $-0.848(0.440)$ & 0.428 & $-0.301(0.332)$ & 0.740 \\
\hline \multicolumn{7}{|l|}{ Variance Components } \\
\hline $\begin{array}{l}\text { Variance intercept } \\
\text { between individuals }\end{array}$ & $0.000(0.000)$ & 1.000 & $0.000(0.000)$ & 1.000 & $0.000(0.000)$ & 1.000 \\
\hline $\begin{array}{l}\text { Variance slope of time } \\
\text { between individuals }\end{array}$ & $0.005^{* *}(0.001)$ & 1.005 & $0.000(0.000)$ & 1.000 & $0.005^{* *}(0.001)$ & 1.005 \\
\hline $\begin{array}{l}\text { Covariance intercept/slope } \\
\text { of time between } \\
\text { individuals }\end{array}$ & $0.000(0.000)$ & 1.000 & $0.000(0.000)$ & 1.000 & $0.000(0.000)$ & 1.000 \\
\hline $\begin{array}{l}\text { Variance intercept } \\
\text { between classes }\end{array}$ & $0.305(0.258)$ & 1.357 & $0.359^{*}(0.162)$ & 1.432 & $0.307(0.271)$ & 1.359 \\
\hline $\begin{array}{l}\text { Variance slope of time } \\
\text { between classes }\end{array}$ & $0.001(0.001)$ & 1.001 & $0.000(0.000)$ & 1.000 & $0.001(0.001)$ & 1.001 \\
\hline $\begin{array}{l}\text { Covariance intercept/slope } \\
\text { of time between classes }\end{array}$ & $-0.013(0.011)$ & 0.987 & $0.000(0.000)$ & 1.000 & $-0.013(0.012)$ & 0.987 \\
\hline
\end{tabular}

Note. Enclosed in parentheses: Reference category.

aStudent groups relate to "all classmates", "dominant students", or "friends" depending on the column considered

${ }^{*} p<.05 .{ }^{* *} p<.01$. Significance-test results based on unrounded results. 
Table 6

Prediction of Individual Disruptive Behavior (T2-T4) by the Perceived Proportion of Disruptive Classmates in Different Student Groups (T1) Using Longit. Multi-Level Analyses

\begin{tabular}{|c|c|c|c|c|c|c|}
\hline & $\begin{array}{l}\text { Model 1: } \\
\text { All classmates }\end{array}$ & & $\begin{array}{l}\text { Model 2: } \\
\text { Dominant stud }\end{array}$ & & $\begin{array}{l}\text { Model 3: } \\
\text { Friends }\end{array}$ & \\
\hline & $\log -B(S E)$ & IRR & $\log -B(S E)$ & $I R R$ & $\log -B(S E)$ & $I R R$ \\
\hline Intercept & $2.124^{* *}(0.647)$ & 8.365 & $3.414(0.907)$ & 30.387 & $2.080^{* *}(0.679)$ & 8.004 \\
\hline
\end{tabular}

Level 1: Time

\begin{tabular}{lllllll}
\hline Time in weeks since T1 & $0.002(0.002)$ & 1.002 & $0.000(0.002)$ & 1.000 & $0.002(0.002)$ & 1.002 \\
\hline
\end{tabular}

Level 2: Individual

\begin{tabular}{|c|c|c|c|c|c|c|}
\hline $\begin{array}{l}\text { Perceived proportion of } \\
\text { aggressive classmates in } \\
\text { student group }\end{array}$ & $0.010^{* *}(0.002)$ & 1.010 & $0.002^{*}(0.001)$ & 1.002 & $0.004^{* *}(0.001)$ & 1.004 \\
\hline Gender (girl) & $0.168^{* *}(0.065)$ & 1.183 & $0.069(0.096)$ & 1.071 & $0.121(0.067)$ & 1.129 \\
\hline Immigration (no immigr.) & $-0.049(0.083)$ & 0.952 & $0.069(0.124)$ & 1.071 & $-0.022(0.086)$ & 0.978 \\
\hline Socio-economic status & $0.006^{* *}(0.002)$ & 1.006 & $0.009^{* *}(0.003)$ & 1.009 & $0.005^{*}(0.002$ & 1.005 \\
\hline Impulsivity & $1.880^{* *}(0.156)$ & 6.554 & $1.698^{* *}(0.229)$ & 5.463 & $1.809^{* *}(0.163)$ & 6.104 \\
\hline $\begin{array}{l}\text { Outside-of-class friends' } \\
\text { behavior }\end{array}$ & $0.137(0.073)$ & 1.145 & $-0.049(0.105)$ & 0.952 & $0.163^{*}(0.078)$ & 1.177 \\
\hline School grades & $-0.155(0.096)$ & 0.856 & $-0.257(0.144)$ & 0.773 & $-0.130(0.101)$ & 0.878 \\
\hline Parental support & $-0.252^{* *}(0.078)$ & 0.777 & $-0.259^{*}(0.118)$ & 0.772 & $-0.204^{*}(0.081)$ & 0.815 \\
\hline \multicolumn{7}{|l|}{ Level 3: Classroom } \\
\hline High academic track (low) & $0.209(0.136)$ & 1.232 & $-0.039(0.179)$ & 0.962 & $0.125(0.142)$ & 1.133 \\
\hline $\begin{array}{l}\text { Middle academic track } \\
\text { (low) }\end{array}$ & $0.178(0.112)$ & 1.195 & $-0.004(0.147)$ & 0.996 & $0.091(0.117)$ & 1.095 \\
\hline $\begin{array}{l}\text { Special educational track } \\
\text { (low) }\end{array}$ & $-0.249(0.197)$ & 0.780 & $-0.161(0.301)$ & 0.851 & $-0.066(0.212)$ & 0.936 \\
\hline $\begin{array}{l}\text { Teacher's support } \\
\text { aggregated in class }\end{array}$ & $0.038(0.168)$ & 1.039 & $-0.217(0.215)$ & 0.805 & $0.052(0.176)$ & 1.053 \\
\hline \multicolumn{7}{|l|}{ Variance Components } \\
\hline $\begin{array}{l}\text { Variance intercept } \\
\text { between individuals }\end{array}$ & $0.790^{* *}(0.092)$ & 2.203 & $0.738^{* *}(0.128)$ & 2.092 & $0.798^{* *}(0.095)$ & 2.221 \\
\hline $\begin{array}{l}\text { Variance slope of time } \\
\text { between individuals }\end{array}$ & $0.001^{* *}(0.000)$ & 1.001 & $0.001^{* *}(0.000)$ & 1.001 & $0.001^{* *}(0.000)$ & 1.001 \\
\hline $\begin{array}{l}\text { Covariance intercept/slope } \\
\text { of time between } \\
\text { individuals }\end{array}$ & $-0.013^{* *}(0.003)$ & 0.987 & $-0.012^{* *}(0.004)$ & 0.988 & $-0.013^{* *}(0.003)$ & 0.987 \\
\hline $\begin{array}{l}\text { Variance intercept } \\
\text { between classes }\end{array}$ & $0.086^{*}(0.040)$ & 1.090 & $0.738^{* *}(0.128)$ & 2.092 & $0.092^{*}(0.043)$ & 1.096 \\
\hline $\begin{array}{l}\text { Variance slope of time } \\
\text { between classes }\end{array}$ & $0.000(0.000)$ & 1.000 & $0.000(0.000)$ & 1.000 & $0.000(0.000)$ & 1.000 \\
\hline $\begin{array}{l}\text { Covariance intercept/slope } \\
\text { of time between classes }\end{array}$ & $-0.001(0.001)$ & 0.999 & $0.000(0.000)$ & 1.000 & $-0.001(0.001)$ & 0.999 \\
\hline
\end{tabular}

Note. Enclosed in parentheses: Reference category.

aStudent groups relate to "all classmates", "dominant students", or "friends" depending on the column considered

${ }^{*} p<.05 .{ }^{* *} p<.01$. Significance-test results based on unrounded results. 
Table 7

Comparisons of the Different Model Fits Using the Vuong Test

\begin{tabular}{lll}
\hline Aggression & Model 2: Dominant students & Model 3: Friends \\
\hline $\begin{array}{l}\text { Model 1: All classmates } \\
\text { Model 2: Dominant students }\end{array}$ & $\mathrm{V}^{\mathrm{a}}=1.18 ; \mathrm{p}=.119$ & $\mathrm{~V}^{\mathrm{a}}=1.35 ; \mathrm{p}=.089$ \\
\hline Delinquency & & $\mathrm{V}^{\mathrm{a}}=0.07 ; \mathrm{p}=.471$ \\
\hline & Model 2: Dominant students & Model 3: Friends \\
Model 1: All classmates & $\mathrm{V}^{\mathrm{a}}=-0.78 ; \mathrm{p}=.217$ & $\mathrm{~V}^{\mathrm{a}}=0.10 ; \mathrm{p}=.460$ \\
Model 2: Dominant students & & $\mathrm{V}^{\mathrm{a}}=0.96 ; \mathrm{p}=.170$ \\
\hline $\begin{array}{l}\text { Disruptive classroom } \\
\text { behavior }\end{array}$ & \\
\hline & & \\
Model 1: All classmates & $\mathrm{V}^{\mathrm{a}}=0.16 ; \mathrm{p}=.440$ & $\mathrm{~V}^{\mathrm{a}}=0.88 ; \mathrm{p}=.190$ \\
Model 2: Dominant students & & $\mathrm{V}^{\mathrm{a}}=0.70 ; \mathrm{p}=.241$ \\
\hline a Vuong non-nested hypothesis test-statistic &
\end{tabular}

a Vuong non-nested hypothesis test-statistic 